\title{
A Humanização no Trabalho do Assistente Social na Área da Saúde e Reabilitação.
}

\author{
Fernandes, Talita Fernanda Stabile \\ Hospital de Reabilitação de Anomlias Craniofaciais - Universidade de São Paulo - \\ talitasfernandes@usp.br
}

INTRODUÇÃO o assistente social na área da saúde e reabilitação compõe a equipe interdisciplinar e é o profissional responsável por conhecer e transmitir a realidade socioeconômica e cultural dos pacientes/famílias, bem como, os aspectos familiares, escolares, profissionais e sociais (GRACIANO, 2013). em sua atuação são trabalhadas questões relacionadas à humanização na saúde, como: às expectativas com tratamento, preconceito sofrido em virtude da deficiência, relacionamento familiar, escolar e social, redes de apoio ao processo de reabilitação, as relações sociais, fortalecimento de vínculos familiares, comunitários e orientações sociais à população atendida quanto aos seus direitos sociais e de cidadania. OBJETIVOS Relatar a prática profissional humanizada do assistente social na área da saúde e reabilitação. MÉTODOS Trata-se de um relato de experiência profissional, tendo como base as ações do Assistente Social na equipe interdisciplinar do Hospital de referência do estudo no período de Fevereiro de 2012 à Dezembro de 2013. RESULTADOS As ações desenvolvidas pelo Assistente Social no hospital estudado são baseadas nos Parâmetros para atuação do assistente social na saúde (CFESS, 2010), categorizando-se em: - Atendimento Direto aos Usuários (ações socioassistenciais, de articulação interdisciplinar e socioeducativas); - Mobilização, Participação e Controle Social; - Investigação, Planejamento e Gestão; e - Assessoria, Qualificação e Formação Profissional Nestas ações, verifica-se o elo existente entre a humanização com a proposta da Reforma Sanitária Brasileira, bem como os princípios norteadores do Sistema Único de Saúde. Sabe-se que a Reforma Sanitária Brasileira nasce da defesa de valores como a democracia direta, o controle social, a universalização de direitos, a humanização da assistência, tendo como concepção o fato de que o cidadão não é cliente, não é usuário, mas é sujeito (CADERNOS HUMANIZA SUS, 2010). Nesta perspectiva, a humanização no trabalho profissional do Serviço Social na equipe interdisciplinar do hospital estudado ultrapassa aquela concepção romântica do trato, cuidado e caridade com os pacientes/famílias. Trata-se de um olhar ampliado dos usuários do serviço de saúde, atendendo-os na sua integralidade e totalidade e respeitando-os enquanto cidadãos, capazes de serem sujeitos da transformação de sua própria história e interpretadores da sua situação de saúde-doença. CONCLUSÕES Diante do exposto, as demandas trazidas pelos pacientes e famílias na saúde e reabilitação representa desafios para Serviço Social e a equipe interdisciplinar. Seu enfrentamento de forma humanizada começa com o conhecimento aproximado da realidade familiar, cultural e social deste público para decifrar as expressões da questão social que os envolve e se estende à intervenção com a participação dos mesmos, contribuindo também para efetivação dos direitos humanos, sociais e de cidadania.

Fernandes, Talita Fernanda Stabile. A Humanização no Trabalho do Assistente Social na Área da Saúde e Reabilitação.. In: Anais do Congresso Internacional de Humanidades \& Humanização em Saúde [= Blucher Medical Proceedings, num.2, vol.1]. São Paulo: Editora Blucher, 2014. ISSN 2357-7282

DOI 10.5151/medpro-cihhs-10199 